\title{
High production of hydrogen on demand from silanes catalyzed by iridium complexes as a versatile hydrogen storage system.
}

David Ventura-Espinosa, Sara Sabater, Alba Carretero-Cerdan, Miguel Baya, and Jose Antonio Mata

ACS Catal., Just Accepted Manuscript • DOI: 10.1021/acscatal.7b04479 • Publication Date (Web): 13 Feb 2018

Downloaded from http://pubs.acs.org on February 16, 2018

\section{Just Accepted}

"Just Accepted" manuscripts have been peer-reviewed and accepted for publication. They are posted online prior to technical editing, formatting for publication and author proofing. The American Chemical Society provides "Just Accepted" as a service to the research community to expedite the dissemination of scientific material as soon as possible after acceptance. "Just Accepted" manuscripts appear in full in PDF format accompanied by an HTML abstract. "Just Accepted" manuscripts have been fully peer reviewed, but should not be considered the official version of record. They are citable by the Digital Object Identifier (DOI®). "Just Accepted" is an optional service offered to authors. Therefore, the "Just Accepted" Web site may not include all articles that will be published in the journal. After a manuscript is technically edited and formatted, it will be removed from the "Just Accepted" Web site and published as an ASAP article. Note that technical editing may introduce minor changes to the manuscript text and/or graphics which could affect content, and all legal disclaimers and ethical guidelines that apply to the journal pertain. ACS cannot be held responsible for errors or consequences arising from the use of information contained in these "Just Accepted" manuscripts. 


\title{
High Production of Hydrogen on Demand from Silanes Catalyzed by Iridium Complexes as a Versatile Hydrogen Storage System
}

\author{
David Ventura-Espinosa, ${ }^{a}$ Sara Sabater, ${ }^{\mathrm{a}}$ Alba Carretero-Cerdán, ${ }^{\mathrm{a}}$ Miguel Baya, ${ }^{\mathrm{b}}$ and Jose A. \\ Mata $^{* a}$ \\ ${ }^{a}$ Institute of Advanced Materials (INAM), Universitat Jaume I, Avda. Sos Baynat s/n, 12006, \\ Castellón (Spain). Fax: (+34) 964387522; Tel.: (+34) 964387516; e-mail: jmata@uji.es \\ bInstituto de Síntesis Química y Catálisis Homogénea (ISQCH), Departamento de Química Inorgánica, \\ CSIC-Universidad de Zaragoza, C/Pedro Cerbuna 12, E-50009 Zaragoza (Spain)
}

\begin{abstract}
The catalytic dehydrogenative coupling of silanes and alcohols represents a convenient process to produce hydrogen on demand. The catalyst, an iridium complex of the formula $\left[\operatorname{IrCp} *(\mathrm{Cl})_{2}(\mathrm{NHC})\right]$ containing an NHC ligand functionalized with a pyrene tag, catalyzes efficiently the reaction at room temperature producing $\mathrm{H}_{2}$ quantitatively within a few minutes. As a result, the dehydrogenative coupling of 1,4-disilabutane and methanol enables an effective hydrogen storage capacity of $4.3 \mathrm{wt} \%$ that is as high as the hydrogen contained in the dehydrogenation of formic acid, positioning the silane/alcohol pair as a potential liquid organic hydrogen carrier for energy storage. In addition, the heterogenization of the iridium complex on graphene presents a recyclable catalyst that retains its activity for at least ten additional runs. The homogeneous distribution of catalytic active sites on the basal plane of graphene prevents diffusion problems and the reaction kinetics are maintained after immobilization.
\end{abstract}

Keywords: hydrogen production, LOHC, iridium, energy storage, supported catalysis, graphene 


\section{Introduction}

Hydrogen is in a leading position among all possible clean alternative sources of energy that will have an impact in the near future due to a rising global demand. ${ }^{1-4}$ The combination of hydrogen with oxygen produces clean energy where the only by-product is water. The actual limitation of using hydrogen to obtain clean energy lies in the development of efficient methods for hydrogen storage. ${ }^{5-8}$ Among them, hydrogen storage in the form of organic liquids is becoming a very attractive strategy because the energy storage density and tractability are similar to actual carbon-based fuels. ${ }^{9-11}$ Liquid organic hydrogen carriers (LOHCs) in combination with a "green hydrogen production" method, i.e., the electrolysis of water or water splitting using eolic and/or solar energies, represent a promising technology for a future energy supply. However, the direct use of eolic and solar energies is limited due to the intermittent characteristics of wind and sun. ${ }^{12-14}$ An increase in these renewable energies is subjected to the availability of efficient energy storage systems. ${ }^{15,16}$

An LOHC is an organic substance that stores hydrogen reversibly in the form of chemical bonds. ${ }^{17-24}$ From a chemical point of view, $\mathrm{H}_{2}$ loading is a hydrogenation reaction, and the reverse process, is a dehydrogenation reaction. The bond-breaking and bond-formation transformations can be driven thermally, but the activation energy required makes the process unfeasible. ${ }^{25}$ The introduction of a catalyst reduces the temperature of both processes, which considerably decreases the required activation energy and controls the kinetics. ${ }^{26-28}$ Herein, a major challenge is to develop efficient methods for hydrogen release. ${ }^{29-32} \mathrm{H}_{2}$ unloading must proceed at low temperatures and with a control of the hydrogen flow. In this regard, we have recently reported ruthenium complexes of type $\left[\mathrm{Ru}(\right.$ arene $\left.)(\mathrm{Cl})_{2}(\mathrm{NHC})\right]$ that are effective catalysts for the dehydrogenative coupling of silanes and alcohols under mild thermal conditions. This process has three main advantages in comparison with traditional ones: (1) hydrogen is obtained at low temperatures, even below $0{ }^{\circ} \mathrm{C}$, which facilitates the potential use of silanes for on-board vehicle applications, ${ }^{33-35}$ (2) the gas is released in short reaction times and the kinetic-control permits the production of a constant flow of hydrogen, and (3) the use of silanes as LOHCs is a carbon free process that produces high-purity hydrogen. Our previous work in ruthenium catalysts used in the coupling of silanes with alcohols show low to moderate hydrogen storage capacity. ${ }^{36}$ In this work, we have developed an active catalytic system based on iridium $\left[\operatorname{IrCp} *(\mathrm{Cl})_{2}(\mathrm{NHC})\right]$ that increases the hydrogen storage capacity up to $4.3 \mathrm{wt} \%$ of $\mathrm{H}_{2}$ (Scheme 1 ).

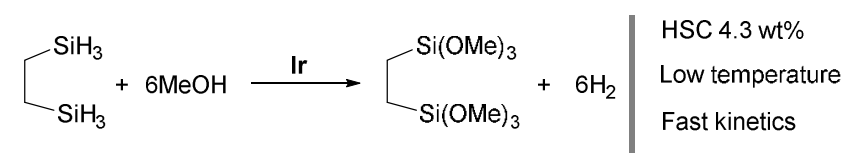

Scheme 1. Hydrogen production by the dehydrogenative coupling of 1,4-disilabutane and methanol 


\section{Results and Discussion}

The reaction of hydrosilanes with alcohols was investigated using $\mathrm{Cp} * \operatorname{Ir}(\mathrm{NHC})$ complexes at a molecular level or supported on graphene (Scheme 2). The reaction of imidazolium salt 1 with $\left[\mathrm{Cp}^{*} \mathrm{IrCl}_{2}\right]_{2}$ under transmetallation conditions using $\mathrm{Ag}_{2} \mathrm{O}$ produced the orthometallated iridium complex 2. Carbon-hydrogen activation processes are commonly observed in chelation-assisted aromatic Cp*Ir complexes. ${ }^{37-40}$ Non-orthometallated iridium complex $\mathbf{3}$ was obtained by deprotonation of the imidazolium salt with $t \mathrm{BuOK}$ and metalation at room temperature. The addition of a second equivalent of base promotes orthometallation forming complex $\mathbf{2}$. The iridium molecular complexes were characterized by NMR spectroscopy, ESI-MS spectrometry and elemental analysis. The immobilization of iridium complex 3 on graphene was carried out as previously described. ${ }^{41-43}$ This methodology allows a controlled grafting of molecular complexes on the surface of reduced graphene oxide (rGO) by $\pi$-staking interactions. We have observed that the pyrene tag forms strong $\pi$-interactions with graphene, which prevents desorption of the molecular complex during the catalytic experiments. ${ }^{44,45}$ Direct evidence for $\pi$-stacking interactions due to the pyrene tag was observed using single-crystal X-ray diffraction of compound 2 (Figure 1). Suitable single crystals were obtained after halide exchange using $\mathrm{NaBr}$. The packing diagram shows a strong $\pi$-stacking interaction between the pyrene groups of different molecules. The interplanar distance between the polyaromatic groups is 3.5 $\AA$. The tendency of the pyrene tag to form $\pi$-stacking interactions has previously been observed for palladium, ${ }^{41}$ ruthenium ${ }^{44}$ and gold. ${ }^{46}$ The formation of $\pi-\pi$ interactions at the molecular level leads to the immobilization of the molecular complexes on the graphene surface. Characterization of the hybrid material 3-rGO was performed by UV/vis, FTIR, HRTEM, and XPS, and the exact amount of complex 3 on graphene was analyzed by ICP/MS analysis (Supporting Information). The results accounted for $6.5 \%$ of iridium complex 3 on the surface of graphene. Analysis by X-ray photoelectron spectroscopy (XPS) provides evidence of the molecular structure of complex $\mathbf{3}$ on the surface of graphene. A comparative XPS analysis of complex 3 and the hybrid material 3-rGO shows the characteristic corelevel peaks of $\mathrm{C} 1 \mathrm{~s}$ and Ir4f at the same binding energy (Figure 2). XPS analysis shows that the mild conditions used during the immobilization process preserved the intrinsic properties of both the iridium complex and graphene. ${ }^{36,46}$ 


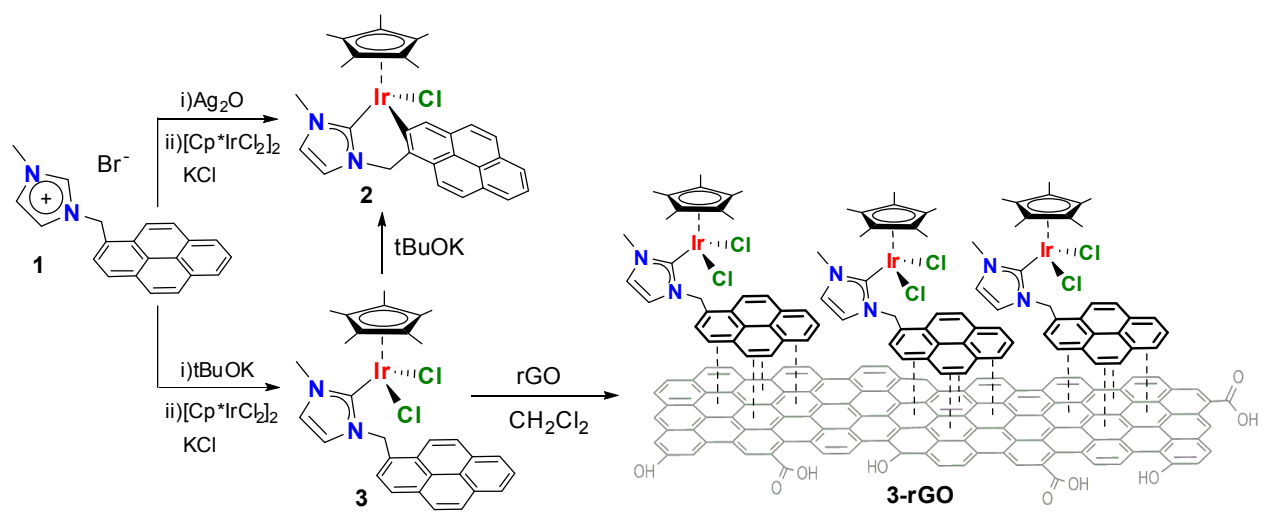

Scheme 2. Synthesis of the iridium molecular complexes and immobilization on graphene

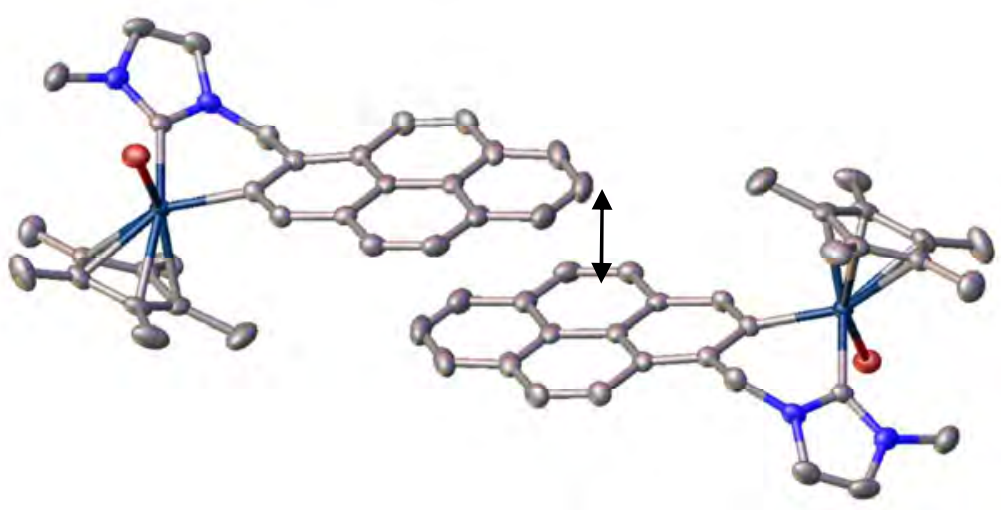

Figure 1. Packing diagram of complex 2 showing an interplanar distance of $3.5 \AA$ between the pyrenes. 

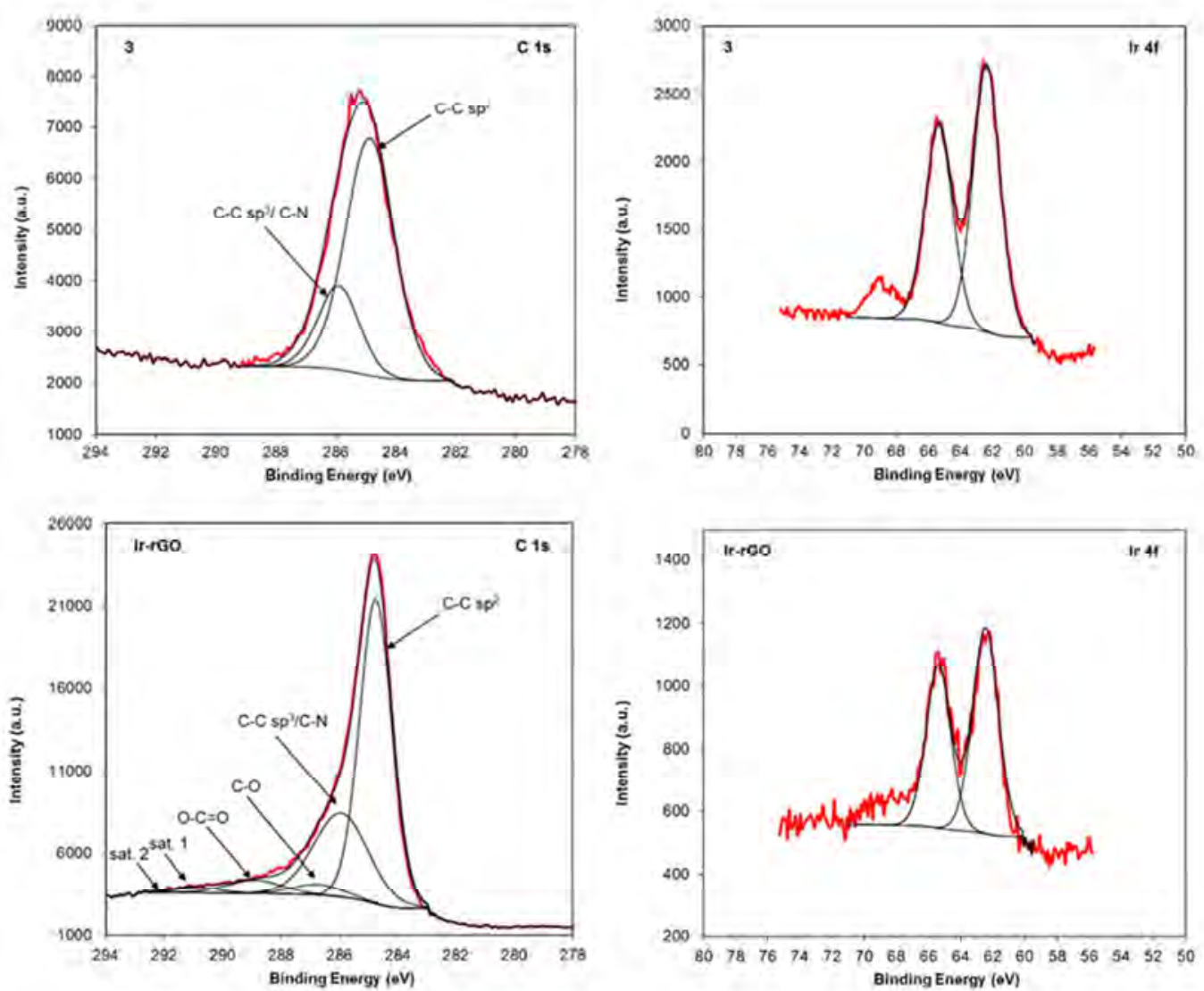

Figure 2. Comparative XPS analysis of molecular complex 3 (top) and hybrid material 3-rGO (down) for the core-level peaks of C1s and Ir4f.

The coupling of silanes with alcohols is a well-known process for the protection of alcohols and the synthesis of silyl ether derivatives. Transition metal complexes are efficient catalysts for this transformation. ${ }^{47-50}$ We used dimethylphenylsilane as a model substrate for the optimization of reaction conditions in the dehydrogenative coupling of the silanes. In a typical experiment, a solution of iridium catalysts in the appropriate alcohol was added to a solution of silane in the same alcohol that was used as the solvent and reagent at $30{ }^{\circ} \mathrm{C}$. Immediately, the reaction starts bubbling hydrogen that was collected using an inverted burette or a pressure transducer. At the end of the reaction, the yield was evaluated by isolation of the silyl ether product. The catalytic activity of the orthometallated iridium complex 2 was low and was not further investigated. In contrast, the iridium complex $\mathbf{3}$ is an efficient catalyst for the dehydrogenative coupling of silanes and alcohols. Using $1.0 \mathrm{mmol}$ of dimethylphenylsilane, $\mathrm{MeOH}$ and a catalyst loading of $0.5 \mathrm{~mol} \%$, the reaction was completed in less than $2 \mathrm{~min}$ at room temperature. The reaction kinetics are slightly different when measuring the generated hydrogen with an inverted burette or a pressure transducer due to a change in the reaction conditions (Figure 3.a). Additionally, at the end 
of the reaction, the silyl ether product was isolated by solvent removal and the yield was evaluated by ${ }^{1} \mathrm{H}$ NMR spectra using anisole or trimethoxybenzene as a standard. The dehydrogenative coupling of dimethylphenylsilane works for different alcohols using catalyst $\mathbf{3}$. The reaction rates rapidly decrease with an elongation of the alcohol chain, and for secondary alcohols, the process is so slow that quantitative yields are not achieved in $80 \mathrm{~min}$ (Figure 3.b). The control of the reaction kinetics is important for industrial applications, especially in the case of hydrogen release from an LOHC connected to a fuel cell. ${ }^{51}$ Herein, we shown that the dynamics are controlled by the use of an appropriate alcohol that can be adjusted to the operation dynamics of the fuel cell.
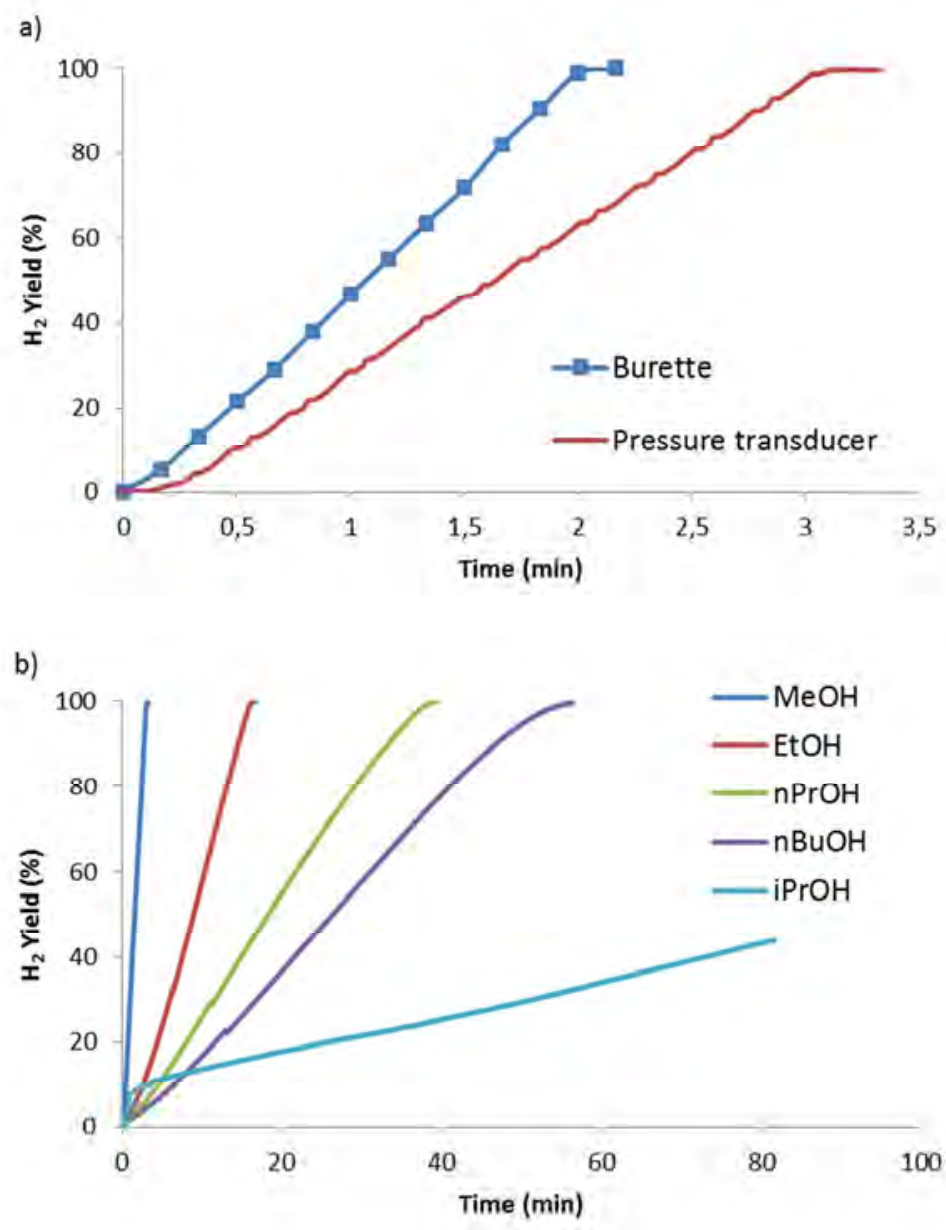

Figure 3. a) Hydrogen evolution monitoring for the reaction of $\mathrm{Ph}(\mathrm{Me})_{2} \mathrm{SiH}$ with $\mathrm{MeOH}(1 \mathrm{~mL})$ at 30 ${ }^{\circ} \mathrm{C}$ using catalyst $3(0.5 \mathrm{~mol} \%)$. b) Dehydrogenative coupling of $\mathrm{Ph}(\mathrm{Me})_{2} \mathrm{SiH}$ with different alcohols (1 $\mathrm{mL})$ using catalyst $3(0.5 \mathrm{~mol} \%)$. Yields obtained using a pressure transducer.

Complex $\mathbf{3}$ is an active catalyst for the coupling of a variety of silanes and alcohols (Table 1). The structural versatility of silanes and the variety of alcohols allows the formation of mixtures with 
controlled properties such as the boiling point, density or hydrogen storage capacity. The dehydrogenative coupling of silanes with alcohols catalyzed by complex $\mathbf{3}$ is sensitive to silane bulkiness and the alcohol nucleophilic character. Quantitative yields are obtained in the coupling of primary, secondary and tertiary silanes with alcohols at low temperature. In all cases, the reaction kinetics is rapid even at $30^{\circ} \mathrm{C}$. The reaction rates are very fast for the primary alcohols and decrease with chain elongation (Table 1, entries 1-4). Bulky silanes such as diphenylsilane, do not reach quantitative yields even after a $2 \mathrm{~h}$ reaction time (Table 1, entry 5). The hydrogen storage capacity of silanes containing a single hydride is low. For instance, the hydrogen content of $\mathrm{Ph}(\mathrm{Me})_{2} \mathrm{SiH} / \mathrm{MeOH}$ is only $1.2 \mathrm{wt} \%$ of $\mathrm{H}_{2}$ (Table 1 , entry 1 ). However, the versatility of hydrosilanes increases the hydrogen storage capacity when using secondary or tertiary hydrosilanes. The effective hydrogen storage capacity of phenylsilane/MeOH increases up to $3.0 \mathrm{wt} \%$ (Table 1, entry 9) and in the case of 1,4disilabutane/MeOH the hydrogen storage capacity is $4.3 \mathrm{wt} \%$ of $\mathrm{H}_{2}$. This is as high as the hydrogen contained using formic acid as an LOHC.

Table 1. Scope of the dehydrogenative coupling of silanes and alcohols.

\begin{tabular}{|c|c|c|c|c|c|}
\hline Entry & Silane & $\mathrm{ROH}$ & eff HSC & $t(\min )$ & Yield $(\%)^{c}$ \\
\hline 1 & & $\mathrm{MeOH}$ & 1.2 & 3 & $100(98)$ \\
\hline 2 & & $\mathrm{EtOH}$ & 1.1 & 30 & $100(97)$ \\
\hline 3 & & $n \mathrm{PrOH}$ & 1.0 & 40 & $100(98)$ \\
\hline 4 & & $n \mathrm{BuOH}$ & 0.96 & 55 & 100(99) \\
\hline 3 & & $\mathrm{MeOH}$ & 1.4 & 20 & 100 \\
\hline 4 & & $\mathrm{EtOH}$ & 1.2 & 30 & 100 \\
\hline 5 & & $\mathrm{MeOH}$ & 1.6 & 120 & $85(82)$ \\
\hline 6 & & $\mathrm{MeOH}$ & 3.0 & 5 & 100 \\
\hline 7 & & $\mathrm{EtOH}$ & 2.5 & 15 & $100(94)$ \\
\hline 8 & & $\mathrm{MeOH}$ & 2.8 & 20 & $100(93)$ \\
\hline 9 & & $\mathrm{EtOH}$ & 2.3 & 35 & $100(90)$ \\
\hline 10 & & $\mathrm{MeOH}$ & 3.3 & 15 & $100(75)$ \\
\hline 11 & & $\mathrm{EtOH}$ & 2.7 & 20 & $96(80)$ \\
\hline 12 & & $\mathrm{MeOH}$ & 4.3 & 12 & $100(96)$ \\
\hline $13^{\mathrm{b}}$ & & $\mathrm{EtOH}$ & 3.3 & 30 & 100(97) \\
\hline $14^{\mathrm{c}}$ & & $n \mathrm{PrOH}$ & 2.7 & 25 & 100 \\
\hline
\end{tabular}




\begin{tabular}{l}
$15^{\mathrm{c}} \mathrm{nBuOH}$ \\
\hline Reaction conditions: silane $(1.0 \mathrm{mmol})$, iridium catalyst $(0.5$ \\
mol\%), $30{ }^{\circ} \mathrm{C}$ and $1 \mathrm{~mL}$ of $\mathrm{ROH}$. [a] Yields determined by \\
$\mathrm{H}_{2}$ formation using an inverted burette and/or a pressure \\
transducer. Isolated yields in parenthesis based on the \\
amount of silyl ether determined by ${ }^{1} \mathrm{H}$ NMR spectroscopic \\
analysis using 1,3,5-trimethoxy benzene as an external \\
standard. [b] Iridium catalyst $(1 \mathrm{~mol} \%)$. [c] Iridium catalyst \\
$(2$ mol\%).
\end{tabular}

The immobilization of molecular complex $\mathbf{3}$ on graphene leads to the formation of a hybrid material composed of an organometallic complex on the surface of reduced graphene oxide. The catalytic properties of 3-rGO were evaluated in the dehydrogenative coupling of silanes and alcohols. The coupling of dimethylphenylsilane and $\mathrm{MeOH}$ using catalyst loading based on iridium of $0.5 \mathrm{~mol} \%$ produces a $100 \%$ yield in $7 \mathrm{~min}$. The comparison of the catalytic activity at a molecular level $(100 \%$ yield in $3 \mathrm{~min}$ ) and the support reveals that the catalytic activity is maintained. In most cases, the immobilization of molecular catalysts leads to a dramatic decrease in activity due to diffusion problems and saturation kinetics. The situation is different when using graphene as a support because all the catalytic centers are located at the surface of the material. The location of the active catalytic species on the surface of a 2D material allows the direct interaction with substrates and diffusion problems are negligible. We have previously observed the same results for other molecular catalysts anchored on the surface of graphene. ${ }^{45}$ Another interesting effect was observed when decreasing the catalyst loading. At a molecular level, we observed that when using a catalyst loading of $0.1 \mathrm{~mol} \%$ the reaction of dimethylphenylsilane and $\mathrm{MeOH}$ practically stopped after reaching a 70\% yield after $15 \mathrm{~min}$. In contrast, quantitative yields are obtained when using the hybrid material 3-rGO. This result is an indication that the reduced graphene oxide is stabilizing the catalytic active species. Graphene is not only acting as a mere support but also interacting with the catalytic active species. An enhancement in the catalytic activity and stability has been observed in the internal hydroamination of alkynes using gold catalysts immobilized on graphene. ${ }^{46}$

The recycling properties of the hybrid material 3-rGO were tested using dimethylphenylsilane as a model substrate. The catalytic activity was evaluated using the general conditions previously described (Table 1). After each run, the solid catalyst 3-rGO was removed from the solution by decantation washed with methanol and then reused. The hybrid material 3-rGO was reused up to ten times without a decrease in activity (Figure 4). The results show that the immobilization on graphene leads to a robust 
catalytic hybrid material that is recyclable. The properties of the hybrid material were analyzed by HRTEM microscopy after the recycling experiments (Figure 5). The images show that the single-layer morphology of graphene is preserved after the catalytic experiments. There is no formation of nanoparticles and the EDS elemental analysis shows the presence of homogeneously distributed iridium.
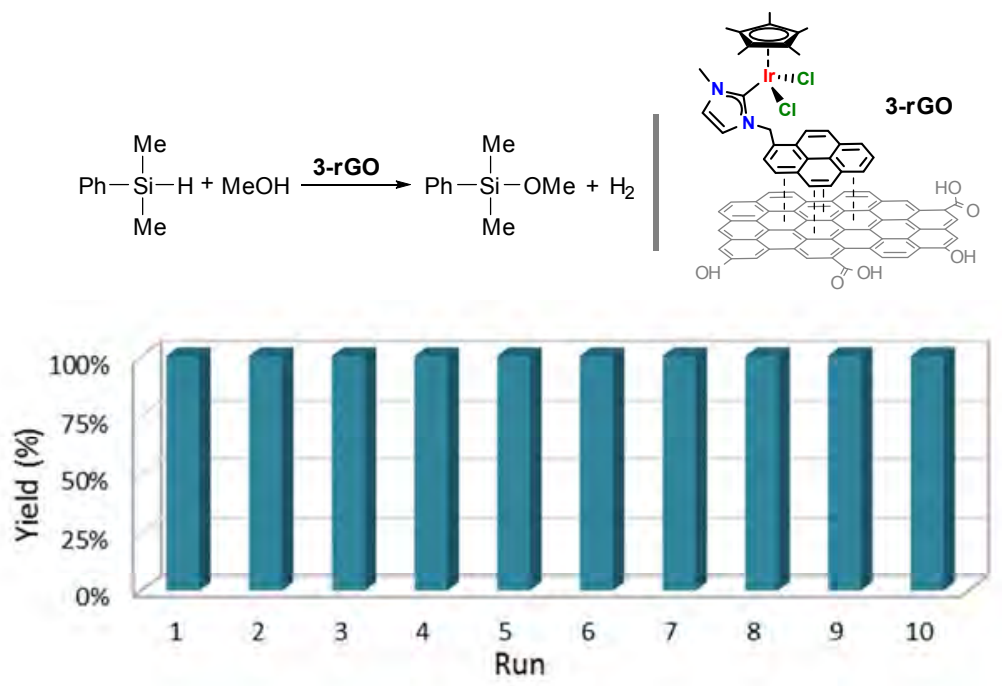

Figure 4. Recycling experiment using $\mathrm{Ph}(\mathrm{Me})_{2} \mathrm{SiH}$. Conditions: Catalyst loading $0.5 \mathrm{~mol} \%, 1.0 \mathrm{mmol}$ of silane, $1 \mathrm{~mL}$ of $\mathrm{MeOH}$ at $30{ }^{\circ} \mathrm{C}$ for $15 \mathrm{~min}$. Yields determined by $\mathrm{GC}$ using anisole as the standard.
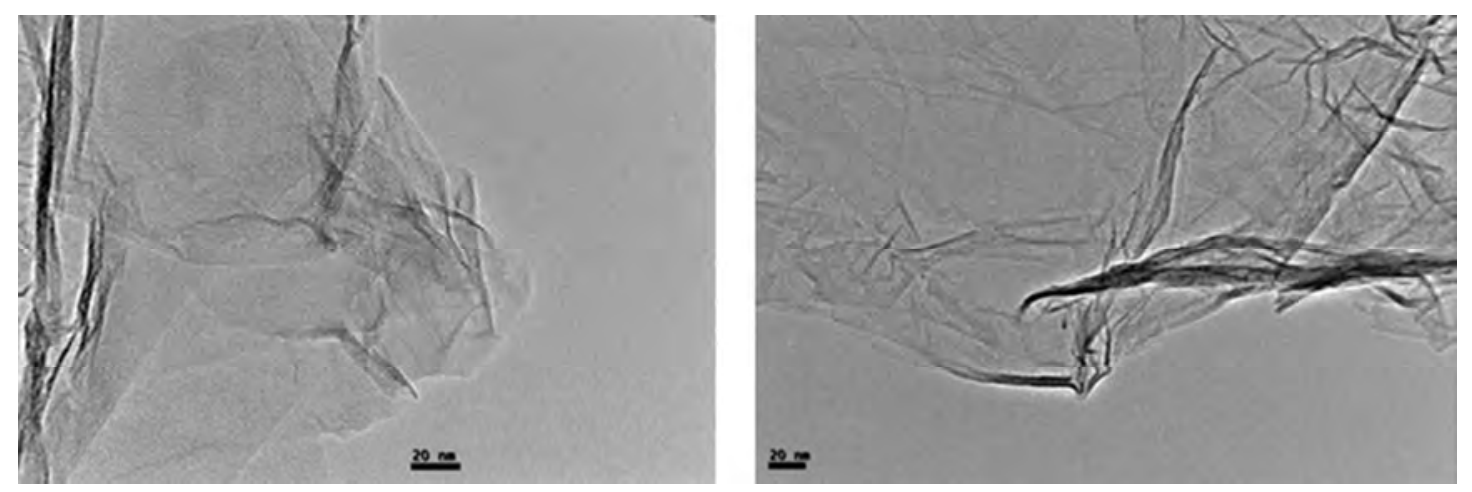

Figure 5. HRTEM images before (left) and after (right) ten catalytic cycles.

The mechanism of the dehydrogenative coupling of silanes with alcohols by homogeneous iridium complexes is based on the interaction of the $\mathrm{Si}-\mathrm{H}$ bond with the metal center forming the reactive metal hydrides. The active hydrides come from the hydrosilanes via oxidative addition or the formation of electrophilic metal/Si-H $\sigma$ complexes. The oxidative addition of a $\mathrm{Si}-\mathrm{H}$ bond to the iridium (III) center is unlikely under reductive alcoholic solutions and most probably is the formation of a metal- $\sigma$ complex. 
The formation a metal/Si-H $\sigma$ complex requires a vacant coordination site that is not present in complex 3. The possible formation of vacant sites in complex 3 were evaluated using different solvents. The ${ }^{1} \mathrm{H}$ NMR spectra of the iridium complexes of type $\left[\mathrm{Cp} * \mathrm{Ir}(\mathrm{Cl})_{2}(\mathrm{NHC})\right]$ in $\mathrm{CDCl}_{3}$ display one set of sharp signals. In contrast, the presence of different species were observed when an NMR analysis was conducted in $\mathrm{CD}_{3} \mathrm{OD}$ ( or $\mathrm{D}_{2} \mathrm{O}$ ). This process is reversible, since the removal of $\mathrm{CD}_{3} \mathrm{OD}$ and the addition of $\mathrm{CDCl}_{3}$ provided the initial spectrum. This finding is indicative of an equilibrium between different metal complexes promoted by $\mathrm{MeOH}$ (Scheme 3). A similar process was observed in the case of Ruarene complexes. ${ }^{52}$ In this context, the iridium complexes of general formula $\left[\mathrm{Cp} * \operatorname{Ir}(\mathrm{Cl})_{2}(\mathrm{NHC})\right]$ are in equilibrium in $\mathrm{MeOH}$ generating cationic species and vacant sites. This equilibrium enhances the electrophilic character of complex $\mathbf{3}$ in alcohols which points to a mechanism based on the formation of a Si-H $\sigma$ complex.

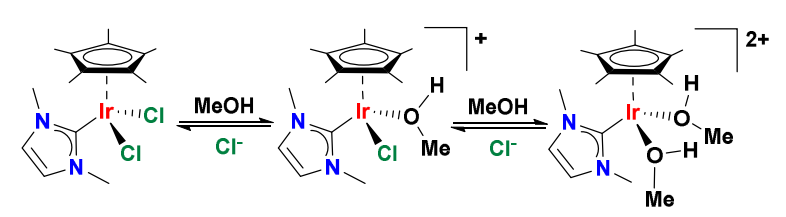

Scheme 3. Equilibrium of $\left[\mathrm{Cp} * \operatorname{Ir}(\mathrm{Cl})_{2}(\mathrm{NHC})\right]$ in a $\mathrm{MeOH}$ solution

The dehydrogenative coupling of silanes with alcohols is a fast reaction even at room temperature, which suggest that the activation energy $\left(\mathrm{E}_{\mathrm{a}}\right)$ is low. To determine the activation energy, a set of reaction profiles were measured at different temperatures. The catalytic reaction of dimethylphenysilane with $\mathrm{MeOH}$ was carried out at different temperatures in the range of 0 to $30^{\circ} \mathrm{C}$. In all cases, quantitative yields were obtained even at $0{ }^{\circ} \mathrm{C}$ (Figure 6). The activation energy obtained from the Arrhenius equation plot is $15.3 \mathrm{Kcal} / \mathrm{mol}$. The coupling of silanes with alcohols is a convenient reaction to produce hydrogen on-demand because it is fast (low activation energy) and the process is thermodynamically favorable $(\Delta \mathrm{G}<0)$.

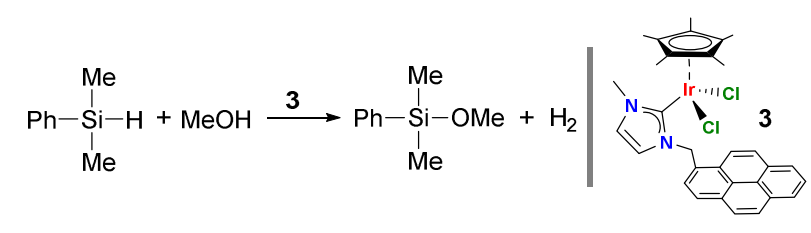


Density functional theory (DFT) calculations were carried out to evaluate the mechanism of the dehydrogenative coupling of dimethylphenylsilane and methanol catalyzed by $[\mathrm{Cp} * \operatorname{Ir}(\mathrm{Cl})(\mathrm{NHC})]^{+}$. The proposed mechanism is based on the experimental evidence and theoretical results (Figure 7). Among the different pathways considered, the most plausible involves a transition metal/Si-H $\sigma$ complex. DFT analysis indicates that the first step of the reaction is an electrophilic activation of the silicon-hydrogen bond. ${ }^{53}$ The electrophilic 16 valence electron $[\mathrm{Cp} * \mathrm{IrCl}(\mathrm{NHC})]^{+}$cation interacts with the hydrogen atom of the silane forming an $\eta^{1}-\mathrm{H}-\mathrm{SiR}_{3}$ complex (A, Figure 7). This type of electrophilic Si-H $\sigma$ complex has been isolated and fully characterized. ${ }^{54}$ Calculations of the Si-H $\sigma$ bond complex reveals that the $\eta^{1}$ coordination prevails over the $\eta^{2}-\mathrm{H}-\mathrm{SiR}_{3}$ and the origin is based on steric factors. In fact, no energy minimum was observed for the $\eta^{2}-\mathrm{H}-\mathrm{SiR}_{3}$ coordination, and an oxidative addition is a highly disfavored process (Section S9). Crabtree et al. introduced the first mechanism proposal based on a transition metal/Si-H $\sigma$ complex. ${ }^{55}$ The presence of vacant sites in the iridium catalysts allows the formation of an $\eta^{2}-\mathrm{H}_{-} \mathrm{SiR}_{3}$ coordination. ${ }^{56-59}$ 
The Ir- $\eta^{1}-\mathrm{H}-\mathrm{SiR}_{3}$ interaction increases the electrophilic character of silicon, which undergoes a nucleophilic attack by the methanol (B, Figure 7). As a result, a neutral iridium hydride and the cation $\mathrm{R}_{3} \mathrm{Si}(\mathrm{H}) \mathrm{OMe}^{+}$are generated. In the next step, the cation $\mathrm{R}_{3} \mathrm{Si}(\mathrm{H}) \mathrm{OMe}^{+}$protonates the iridium hydride forming a dihydrogen complex that finally releases hydrogen gas. As a summary the iridium catalysts facilitates the methanol nucleophilic attack to the silane and favors the release of hydrogen from a metaldihydrogen intermediate.

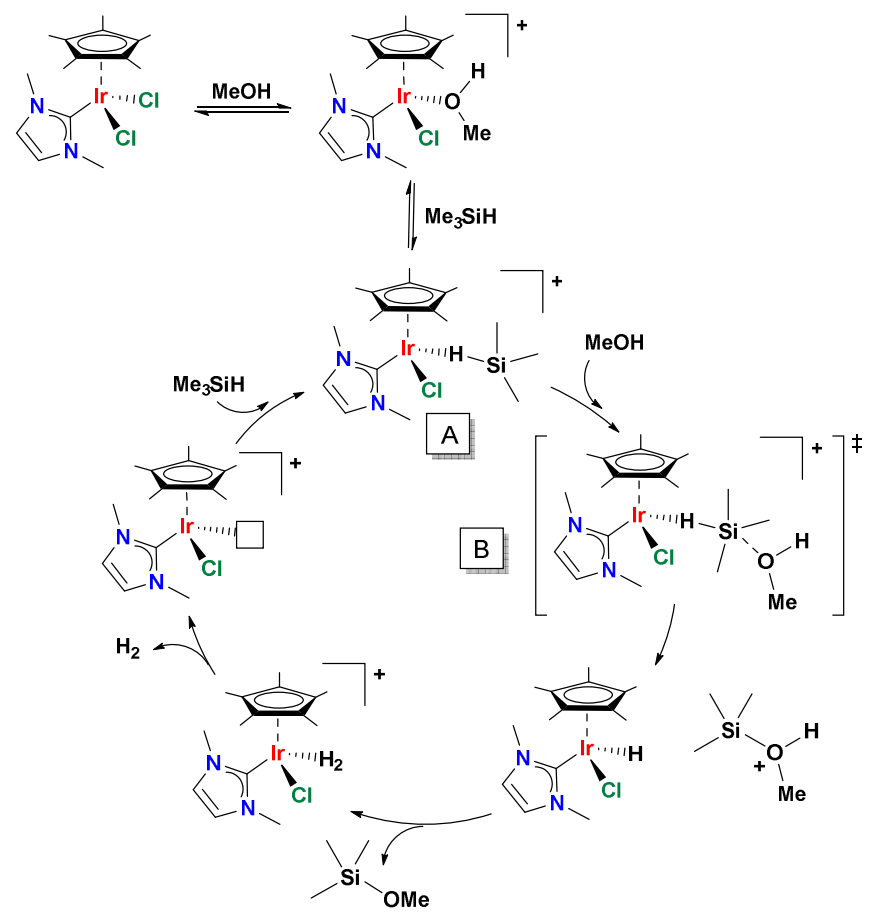

Figure 7. Mechanistic proposal for the dehydrogenative coupling catalyzed by $\left[\operatorname{Ir}\left(\eta^{5}-\right.\right.$ $\left.\left.\mathrm{C}_{5} \mathrm{Me}_{5}\right) \mathrm{Cl}(\mathrm{NHC})\right]^{+}$.

\section{Conclusions}

The dehydrogenative coupling reaction of silanes and alcohols represents a convenient process for the production of hydrogen on-demand using an iridium catalyst of the general formula $\left[\mathrm{IrCp} *(\mathrm{Cl})_{2}(\mathrm{NHC})\right]$. Quantitative yields of hydrogen are obtained in less than five min at $30{ }^{\circ} \mathrm{C}$ by the coupling of dimethylphenylsilane and $\mathrm{MeOH}$ using a catalyst loading of $0.5 \mathrm{~mol} \%$. Hydrogen is produced at high rates, room temperature and without additives, which is convenient for combining hydrogen production with fuel cells. The iridium catalyst is active for sequential additions of silane and highly efficient suggesting that the catalyst is stable and robust. The proposed mechanism, based on the experimental evidence and DFT calculations, reveals the formation of a metal/Si-H $\sigma$ complex. The rate-determining 


\section{Experimental Section}

General procedures. Anhydrous solvents were dried using a solvent purification system. The alcohols used for the catalytic experiments were dried over preactivated molecular sieves of $3 \AA$. All hydrosilanes were obtained from commercial suppliers and used as received. Safety warning: 1,4-disilabutane is a highly flammable liquid and vapors have been reported to spontaneously ignite on contact with air (Gelest). We have not experienced any problems working in alcohol dilution. Imidazolium salt 1 was obtained according to reported procedures. ${ }^{41}$ Nuclear magnetic resonance (NMR) spectra were recorded on Bruker spectrometers operating at 300 or $400 \mathrm{MHz}\left({ }^{1} \mathrm{H} \mathrm{NMR}\right)$ and 75 or $100 \mathrm{MHz}\left({ }^{13} \mathrm{C}\left\{{ }^{1} \mathrm{H}\right\} \mathrm{NMR}\right)$, and referenced to $\mathrm{SiMe}_{4}$ ( $\delta$ in ppm and $\mathrm{J}$ in Hertz). NMR spectra were recorded at room temperature with the appropriate deuterated solvent. High-resolution transmission electron microscopy (HRTEM) and high-angle annular dark-field HAADF-STEM images of the samples were obtained using a JEM2100 LaB6 (JEOL) transmission electron microscope coupled with an INCA Energy TEM 200 (Oxford) energy dispersive X-ray spectrometer (EDX) operating at $200 \mathrm{kV}$. Samples were prepared by drying a droplet of a $\mathrm{MeOH}$ dispersion on a carbon-coated copper grid. X-ray photoelectron spectra (XPS) were acquired on a Kratos AXIS ultra DLD spectrometer with a monochromatic Al Ka X-ray source (1486.6 $\mathrm{eV}$ ) using a pass energy of $20 \mathrm{eV}$. To provide a precise energy calibration, the XPS binding energies were referenced to the $\mathrm{C} 1 \mathrm{~s}$ peak at $284.6 \mathrm{eV}$. Catalytic experiments were monitored using a pressure transducer "Man on the moon" x102 series kit (www.manonthemoon.com) microreactor with a total volume of $38.2 \mathrm{~mL}$. Hydrogen identification was carried out by injecting the generated gas of a typical reaction in in a quadrupole mass spectrometer (Omnistar GSD 32003 from Pfeiffer Vacuum).

General procedure for the catalytic dehydrogenative coupling of silanes and alcohols. The catalytic experiments were performed in a $25 \mathrm{~mL}$ round bottom flask, using 0.5 to $1 \mathrm{mmol}$ of silane, $1 \mathrm{~mL}$ of alcohol, and a catalyst $(0.05-1.00 \mathrm{~mol} \%)$. The flask was heated at $30{ }^{\circ} \mathrm{C}$ under an initial aerobic 
atmosphere. The system was connected to a pressure transducer for monitoring the reaction or was connected to an inverted water-filled burette that was used to collect the released gas. The yields and conversions were determined by GC analysis using anisole as the internal standard. The isolated yields were determined by solvent evaporation and analysis by ${ }^{1} \mathrm{H}$ NMR spectroscopy using $1,3,5-$ trimethoxybenzene as the external standard.

Synthesis of 2. Under the exclusion of light, imidazolium salt 1 (94.7 mg, $0.25 \mathrm{mmol})$ and $\mathrm{Ag}_{2} \mathrm{O}(58.5$ $\mathrm{mg}, 0.25 \mathrm{mmol}$ ) were mixed in $10 \mathrm{~mL}$ of acetonitrile in a round-bottom flask, and the suspension was stirred for $5 \mathrm{~h}$ at room temperature. [ $\left.\mathrm{IrCp}^{*} \mathrm{Cl}_{2}\right]_{2}(100 \mathrm{mg}, 0.125 \mathrm{mmol})$ and $\mathrm{KCl}(243 \mathrm{mg}, 3.25 \mathrm{mmol})$ were added, and the reaction mixture was stirred at room temperature for $15 \mathrm{~h}$. Acetonitrile was removed under reduced pressure, and the mixture was suspended in dichloromethane. The insoluble salts were removed by filtration, and the crude product was purified by flash chromatography, producing 2 as a crystalline orange powder. Yield: $80 \mathrm{mg}(49 \%) .{ }^{1} \mathrm{H} \mathrm{NMR}\left(400 \mathrm{MHz}, \mathrm{CDCl}_{3}\right) \delta 8.67\left(\mathrm{~s}, 1 \mathrm{H}, \mathrm{CH}_{\mathrm{pyr}}\right)$, $8.20\left(\mathrm{~d},{ }^{3} \mathrm{~J}_{\mathrm{H}, \mathrm{H}}=9.4 \mathrm{~Hz}, 1 \mathrm{H}, \mathrm{C} H_{\mathrm{pyr}}\right), 7.98\left(\mathrm{~m}, 6 \mathrm{H}, \mathrm{C} H_{\mathrm{pyr}}\right), 7.07\left(\mathrm{~d},{ }^{3} \mathrm{~J}_{\mathrm{H}, \mathrm{H}}=2.0 \mathrm{~Hz}, 1 \mathrm{H}, \mathrm{C} H_{\text {imid }}\right), 6.88(\mathrm{~d}$, $\left.{ }^{3} \mathrm{~J}_{\mathrm{H}, \mathrm{H}}=2.0 \mathrm{~Hz}, 1 \mathrm{H}, \mathrm{C} H_{\mathrm{imid}}\right), 5.99\left(\mathrm{~d},{ }^{3} \mathrm{~J}_{\mathrm{H}, \mathrm{H}}=14.5 \mathrm{~Hz}, 1 \mathrm{H}, \mathrm{CHH}\right), 5.18\left(\mathrm{~d},{ }^{3} \mathrm{~J}_{\mathrm{H}, \mathrm{H}}=14.5 \mathrm{~Hz}, 1 \mathrm{H}, \mathrm{CH}\right)$, 3,94 (s, 3H, N-CH $), 1.71\left(\mathrm{~s}, 15 \mathrm{H}, \mathrm{CH}_{3}, \mathrm{Cp}^{*}\right) .{ }^{13} \mathrm{C} \mathrm{NMR}\left(101 \mathrm{MHz}, \mathrm{CDCl}_{3}\right): \delta 156.3\left(\mathrm{C}_{\text {carbene-Ir }}\right),[142.3$, 141.2, 132.6, 130.9, 130.3, 129.8, 127.8, 126.1, 125.5, 125.2, 125.1, 124.3, 124.0, 123.5, 121.9, 121.6, 121.2, 120.6] ( $\left.\mathrm{C}_{\mathrm{pyr}}, \mathrm{CH}_{\text {imid }}\right), 90.5\left(\mathrm{Cp}^{*}\right), 51.8\left(\mathrm{CH}_{2}\right), 37.8\left(\mathrm{~N}-\mathrm{CH}_{3}\right), 9.5\left(\mathrm{CH}_{3}-\mathrm{Cp}^{*}\right)$. HRMS ESI-TOFMS (positive mode): $[\mathrm{M}-\mathrm{K}]^{+}$monoisotopic peak 567.0309; calc. 567.0305, $\varepsilon_{\mathrm{r}}: 0.7$ ppm.

Synthesis of 3. In a Schlenk, a mixture of imidazolium salt 1 (95 $\mathrm{mg}, 0.250 \mathrm{mmol})$ and potassium tertbutoxide (33 mg, $0.280 \mathrm{mmol}$ ) was cooled to $0{ }^{\circ} \mathrm{C}$, in an ice bath. Freshly distilled tetrahydrofuran (5 $\mathrm{mL}$ ) was added, and the mixture was stirred for $10 \mathrm{~min}$ and allowed to reach room temperature. Then, $\left[\mathrm{Cp}^{*} \mathrm{IrCl}_{2}\right]_{2}(100 \mathrm{mg}, 0.125 \mathrm{mmol})$ and $\mathrm{KCl}(243 \mathrm{mg}, 3.25 \mathrm{mmol})$ were added and the reaction mixture was stirred for $4 \mathrm{~h}$ at room temperature. The resulting suspension was filtered through celite and the solvent was removed under reduced pressure. The crude solid was purified by column chromatography. An elution with a mixture of dichloromethane and acetone $(9: 1)$ produced the separation of a yellow band containing the desired product. Precipitation from dichloromethane/hexane produced an analytically pure yellow solid. Yield: $111 \mathrm{mg}, 64 \% .{ }^{1} \mathrm{H}$ NMR $\left(300 \mathrm{MHz}, \mathrm{CDCl}_{3}\right): \delta 8.37\left(\mathrm{~d},{ }^{3} \mathrm{~J}_{\mathrm{H}, \mathrm{H}}=9.2\right.$ $\left.\mathrm{Hz}, 1 \mathrm{H}, \mathrm{C} H_{\mathrm{pyr}}\right), 8.25-8.02\left(\mathrm{~m}, 7 \mathrm{H}, \mathrm{C} H_{\mathrm{pyr}}\right), 7.84\left(\mathrm{~d},{ }^{3} \mathrm{~J}_{\mathrm{H}, \mathrm{H}}=7.8 \mathrm{~Hz}, 1 \mathrm{H}, \mathrm{C} H_{\mathrm{pyr}}\right), 6.90\left(\mathrm{~d},{ }^{3} \mathrm{~J}_{\mathrm{H}, \mathrm{H}}=2.1 \mathrm{~Hz}\right.$, $\left.1 \mathrm{H}, \mathrm{C} H_{\text {imid }}\right), 6.66,6.28\left(\mathrm{AB},{ }^{3} \mathrm{~J}_{\mathrm{AB}}=15.1 \mathrm{~Hz}, 2 \mathrm{H}, \mathrm{CH}_{2}\right), 6.65\left(\mathrm{~d},{ }^{3} \mathrm{~J}_{\mathrm{H}, \mathrm{H}}=2.1 \mathrm{~Hz}, 1 \mathrm{H}, \mathrm{C} H_{\text {imid }}\right), 4.07(\mathrm{~s}, 3 \mathrm{H}$, $\left.\mathrm{NCH}_{3}\right), 1.62\left(\mathrm{~s}, 15 \mathrm{H}, \mathrm{C}\left(\mathrm{CH}_{3}\right)_{5}\right) .{ }^{13} \mathrm{C}\left\{{ }^{1} \mathrm{H}\right\} \mathrm{NMR}\left(75 \mathrm{MHz}, \mathrm{CDCl}_{3}\right): \delta 157.1\left(C_{\text {carbene-Ir }}\right),[131.2,131.1$, $130.7,129.8,129.0,128.6,127.7,127.2,126.2,125.9,125.6,125.5,124.7,123.1,122.5,122.3]\left(C_{\text {pyr }}\right.$

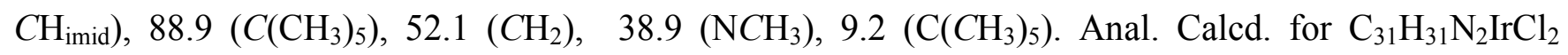
(694.71 g/mol): C, 53.59; H, 4.49; N, 4.03. Found: C, 53.67; H, 4.27; N, 4.37. Electrospray MS. (Cone 
General procedure for the catalytic dehydrogenative coupling of silanes and alcohols.

The catalytic experiments were performed in a $25 \mathrm{~mL}$ round bottom flask using $0.5 \mathrm{mmol}$ of silane, 1 $\mathrm{mL}$ of alcohol, and a catalyst $(0.05-1.00 \mathrm{~mol} \%)$. The flash was heated at $30^{\circ} \mathrm{C}$ in an initial nitrogen atmosphere. The system was connected to a pressure transducer for monitoring the reaction or was connected to an inverted water-filled burette that was used to collect the released gas. The yields and conversions were determined by GC analysis using anisole as internal standard. Isolated yields were determined by solvent evaporation and analysis by ${ }^{1} \mathrm{H}$ NMR spectroscopy using 1,3,5trimethoxybenzene as the external standard.

\section{Corresponding Author}

Jose A. Mata*, anstitute of Advanced Materials (INAM), Universitat Jaume I, Avda. Sos Baynat s/n, 12006, Castellón (Spain). Fax: (+34) 964387522; Tel.: (+34) 964387516; e-mail: jmata@uji.es

\section{Author Contributions}

The manuscript was written with contributions from all authors. All authors have approved the final version of the manuscript.

Supporting information. Experimental details, characterization by NMR spectra and mass spectroscopy, crystallographic data, DFT calculations details, and HRTEM images. CCDC 1811349

\section{Acknowledgments}


The authors are thankful for the financial support from MINECO (CTQ2015-69153-C2-2-R and CTQ2015-67461-P), Diputación General de Aragón (Grupo Consolidado E21) and Universitat Jaume I (P1.1B2015-09). D. V-E thanks the MINECO for the FPU grant (FPU15/03011). The authors are very grateful to the 'Serveis Centrals d'Instrumentació Científica (SCIC)' of the Universitat Jaume I and to the Instituto de Biocomputación y Física de Sistemas Complejos (BIFI) and the Centro de Supercomputación de Galicia (CESGA) for the generous allocation of computational resources.

\section{ABBREVIATIONS}

LOHC, liquid organic hydrogen carrier; HSC, hydrogen storage capacity; NHC, N-heterocyclic carbene.

\section{References}

(1) Zuttel, A.; Remhof, A.; Borgschulte, A.; Friedrichs, O. Hydrogen: The Future Energy Carrier. Philos. Trans. R. Soc. A Math. Phys. Eng. Sci. 2010, 368, 3329-3342.

(2) Midilli, A.; Ay, M.; Dincer, I.; Rosen, M. A. On Hydrogen and Hydrogen Energy Strategies. Renew. Sustain. Energy Rev. 2005, 9, 255-271.

(3) Satyapal, S.; Petrovic, J.; Read, C.; Thomas, G.; Ordaz, G. The U.S. Department of Energy's National Hydrogen Storage Project: Progress towards Meeting Hydrogen-Powered Vehicle Requirements. Catal. Today 2007, 120, 246-256.

(4) Winsche, W. E.; Hoffman, K. C.; Salzano, F. J. Hydrogen: Its Future Role in the Nation's Energy Economy. Science 1973, 180, 1325-1332.

(5) Züttel, A. Materials for Hydrogen Storage. Mater. Today 2003, 6, 24-33.

(6) Sahler, S.; Prechtl, M. H. G. Advancement in Molecular Hydrogen Storage Systems. ChemCatChem 2011, 3, 1257-1259.

(7) Yadav, M.; Xu, Q. Liquid-Phase Chemical Hydrogen Storage Materials. Energy Environ. Sci. 2012, 5, 9698-9725.

(8) Teichmann, D.; Arlt, W.; Wasserscheid, P. Liquid Organic Hydrogen Carriers as an Efficient Vector for the Transport and Storage of Renewable Energy. Int. J. Hydrogen Energy 2012, 37, 18118-18132.

(9) Sartbaeva, A.; Kuznetsov, V. L.; Wells, S. A.; Edwards, P. P. Hydrogen Nexus in a Sustainable Energy Future. Energy Environ. Sci. 2008, 1, 79-85.

(10) Crabtree, G. W.; Dresselhaus, M. S.; Buchanan, M. V. The Hydrogen Economy. Phys. Today 
2004, 57, 39-44.

(11) Marbán, G.; Valdés-Solís, T. Towards the Hydrogen Economy? Int. J. Hydrogen Energy 2007, $32,1625-1637$.

(12) Jena, P. Materials for Hydrogen Storage: Past, Present, and Future. J. Phys. Chem. Lett. 2011, 2, 206-211.

(13) Dalebrook, A. F.; Gan, W.; Grasemann, M.; Moret, S.; Laurenczy, G. Hydrogen Storage: Beyond Conventional Methods. Chem. Commun. 2013, 49, 8735-8751.

(14) Müller, K.; Arlt, W. Hydrogen Based Energy Storage. In Renewable Energy: Economics, Emerging Technologies and Global Practices; Nova Science Publishers, Inc.: New York, 2013; pp. 45-60.

(15) Armaroli, N.; Balzani, V. Energy for a Sustainable World; Wiley-VCH Verlag GmbH \& Co. KGaA: Weinheim, Germany, 2010.

(16) Vladimir, A.; Dejan, G.; Jasmina, G.; Dragica, M. Hydrogen Economy: Modern Concepts, Challenges and Perspectives. In Hydrogen Energy - Challenges and Perspectives; InTech: London, 2012; pp. 3-28.

(17) Crabtree, R. H. Hydrogen Storage in Liquid Organic Heterocycles. Energy Environ. Sci. 2008, 1, 134-138.

(18) Campos, J.; Hintermair, U.; Brewster, T. P.; Takase, M. K.; Crabtree, R. H. Catalyst Activation by Loss of Cyclopentadienyl Ligands in Hydrogen Transfer Catalysis with Cp*IrIII Complexes. ACS Catal. 2014, 4, 973-985.

(19) Preuster, P.; Papp, C.; Wasserscheid, P. Liquid Organic Hydrogen Carriers (LOHCs): Toward a Hydrogen-Free Hydrogen Economy. Acc. Chem. Res. 2017, 50, 74-85.

(20) Markiewicz, M.; Zhang, Y. Q.; Bösmann, A.; Brückner, N.; Thöming, J.; Wasserscheid, P.; Stolte, S. Environmental and Health Impact Assessment of Liquid Organic Hydrogen Carrier (LOHC) Systems - Challenges and Preliminary Results. Energy Environ. Sci. 2015, 8, 10351045.

(21) Han, W. S.; Kim, T. J.; Kim, S. K.; Kim, Y.; Kim, Y.; Nam, S. W.; Kang, S. O. Silane-Based Hydrogen Storage Materials for Fuel Cell Application: Hydrogen Release via Methanolysis and Regeneration by Hydride Reduction from Organosilanes. Int. J. Hydrogen Energy 2011, 36, 12305-12312.

(22) Brunel, J. M. New Efficient Hydrogen Process Production from Organosilane Hydrogen Carriers Derivatives. Int. J. Hydrogen Energy 2010, 35, 3401-3405.

(23) Eberle, U.; Felderhoff, M.; Schüth, F. Chemical and Physical Solutions for Hydrogen Storage. Angew. Chem. Int. Ed. 2009, 48, 6608-6630.

(24) He, T.; Pei, Q.; Chen, P. Liquid Organic Hydrogen Carriers. J. Energy Chem. 2015, 24, 587-594.

(25) Clot, E.; Eisenstein, O.; Crabtree, R. H. Computational Structure-activity Relationships in H 2 Storage: How Placement of N Atoms Affects Release Temperatures in Organic Liquid Storage Materials. Chem. Commun. 2007, 22, 2231-2233. 
(26) Crabtree, R. H. Nitrogen-Containing Liquid Organic Hydrogen Carriers: Progress and Prospects. ACS Sustain. Chem. Eng. 2017, 5, 4491-4498.

(27) Dobereiner, G. E.; Crabtree, R. H. Dehydrogenation as a Substrate-Activating Strategy in Homogeneous Transition-Metal Catalysis. Chem. Rev. 2010, 110, 681-703.

(28) Wang, Z.; Belli, J.; Jensen, C. M. Homogeneous Dehydrogenation of Liquid Organic Hydrogen Carriers Catalyzed by an Iridium PCP Complex. Faraday Discuss. 2011, 151, 297.

(29) Jiang, Z.; Pan, Q.; Xu, J.; Fang, T. Current Situation and Prospect of Hydrogen Storage Technology with New Organic Liquid. Int. J. Hydrogen Energy 2014, 39, 17442-17451.

(30) Pradhan, A. U.; Shukla, A.; Pande, J. V.; Karmarkar, S.; Biniwale, R. B. A Feasibility Analysis of Hydrogen Delivery System Using Liquid Organic Hydrides. Int. J. Hydrogen Energy 2011, 36, 680-688.

(31) Shukla, A.; Karmakar, S.; Biniwale, R. B. Hydrogen Delivery through Liquid Organic Hydrides: Considerations for a Potential Technology. Int. J. Hydrogen Energy 2012, 37, 3719-3726.

(32) Müller, K.; Stark, K.; Emel'yanenko, V. N.; Varfolomeev, M. A.; Zaitsau, D. H.; Shoifet, E.; Schick, C.; Verevkin, S. P.; Arlt, W. Liquid Organic Hydrogen Carriers: Thermophysical and Thermochemical Studies of Benzyl- and Dibenzyl-Toluene Derivatives. Ind. Eng. Chem. Res. 2015, 54, 7967-7976.

(33) Schlapbach, L.; Züttel, A. Hydrogen-Storage Materials for Mobile Applications. Nature 2001, 414, 353-358.

(34) Ahluwalia, R. K.; Wang, X.; Rousseau, A.; Kumar, R. Fuel Economy of Hydrogen Fuel Cell Vehicles. J. Power Sources 2004, 130, 192-201.

(35) Eberle, D. U.; von Helmolt, D. R. Sustainable Transportation Based on Electric Vehicle Concepts: A Brief Overview. Energy Environ. Sci. 2010, 3, 689-699.

(36) Ventura-Espinosa, D.; Carretero-Cerdán, A.; Baya, M.; García, H.; Mata, J. A. Catalytic Dehydrogenative Coupling of Hydrosilanes with Alcohols for the Production of Hydrogen OnDemand: Application of a Silane/Alcohol Pair as a Liquid Organic Hydrogen Carrier. Chem. Eur. J. 2017, 23, 10815-10821.

(37) Arndtsen, B. A.; Bergman, R. G.; Andrew Mobley, T.; Peterson, T. H. Selective Intermolecular Carbon-Hydrogen Bond Activation by Synthetic Metal Complexes in Homogeneous Solution. Acc. Chem. Res. 1995, 28, 154-162.

(38) Viciano, M.; Feliz, M.; Corberán, R.; Mata, J. A.; Clot, E.; Peris, E. Aliphatic versus Aromatic C$\mathrm{H}$ Activation in the Formation of Abnormal Carbenes with Iridium: A Combined Experimental and Theoretical Study. Organometallics 2007, 26, 5304-5314.

(39) Corberán, R.; Sanaú, M.; Peris, E. Highly Stable Cp*-Ir(III) Complexes with N -Heterocyclic Carbene Ligands as $\mathrm{C}-\mathrm{H}$ Activation Catalysts for the Deuteration of Organic Molecules. J. Am. Chem. Soc. 2006, 128, 3974-3979.

(40) Iglesias, D.; Sabater, S.; Azua, A.; Mata, J. a. Catalytic Applications of Magnetic Nanoparticles Functionalized Using Iridium N-Heterocyclic Carbene Complexes. New J. Chem. 2015, 39, 
$6437-6444$.

(41) Sabater, S.; Mata, J. A.; Peris, E. Catalyst Enhancement and Recyclability by Immobilization of Metal Complexes onto Graphene Surface by Noncovalent Interactions. ACS Catal. 2014, 4, 2038-2047.

(42) Sabater, S.; Mata, J. A. Catalytic Applications of Metal Complexes Immobilized by NonCovalent Interactions onto Chemically Derived Graphenes and Related Materials. In Noncovalent Interactions in the Synthesis and Design of New Compounds; John Wiley \& Sons, Inc: Hoboken, NJ, 2016; pp. 313-326.

(43) Ruiz-Botella, S.; Peris, E. Unveiling the Importance of $\pi$-Stacking in Borrowing-Hydrogen Processes Catalysed by Iridium Complexes with Pyrene Tags. Chem. Eur. J. 2015, 21, 1526315271.

(44) Ventura-Espinosa, D.; Vicent, C.; Baya, M.; Mata, J. A. Ruthenium Molecular Complexes Immobilized on Graphene as Active Catalysts for the Synthesis of Carboxylic Acids from Alcohol Dehydrogenation. Catal. Sci. Technol. 2016, 6, 8024-8035.

(45) Ventura-Espinosa, D.; Marzá-Beltrán, A.; Mata, J. A. Catalytic Hydrogen Production by Ruthenium Complexes from the Conversion of Primary Amines to Nitriles: Potential Application as a Liquid Organic Hydrogen Carrier. Chem. Eur. J. 2016, 22, 17758-17766.

(46) Ventura-Espinosa, D.; Sabater, S.; Mata, J. A. Enhancement of Gold Catalytic Activity and Stability by Immobilization on the Surface of Graphene. J. Catal. 2017, 352, 498-504.

(47) Mukherjee, D.; Thompson, R. R.; Ellern, A.; Sadow, A. D. Coordinatively Saturated Tris(oxazolinyl)borato Zinc Hydride-Catalyzed Cross Dehydrocoupling of Silanes and Alcohols. ACS Catal. 2011, 1, 698-702.

(48) Aliaga-Lavrijsen, M.; Iglesias, M.; Cebollada, A.; Garcés, K.; García, N.; Sanz Miguel, P. J.; Fernández-Alvarez, F. J.; Pérez-Torrente, J. J.; Oro, L. A. Hydrolysis and Methanolysis of Silanes Catalyzed by Iridium(III) Bis-N-Heterocyclic Carbene Complexes: Influence of the Wingtip Groups. Organometallics 2015, 34, 2378-2385.

(49) Ison, E. A.; Corbin, R. A.; Abu-Omar, M. M. Hydrogen Production from Hydrolytic Oxidation of Organosilanes Using a Cationic Oxorhenium Catalyst. J. Am. Chem. Soc. 2005, 127, 1193811939.

(50) Sattler, W.; Parkin, G. Zinc Catalysts for on-Demand Hydrogen Generation and Carbon Dioxide Functionalization. J. Am. Chem. Soc. 2012, 134, 17462-17465.

(51) Fikrt, A.; Brehmer, R.; Milella, V.-O.; Müller, K.; Bösmann, A.; Preuster, P.; Alt, N.; Schlücker, E.; Wasserscheid, P.; Arlt, W. Dynamic Power Supply by Hydrogen Bound to a Liquid Organic Hydrogen Carrier. Appl. Energy 2017, 194, 1-8.

(52) Csabai, P.; Joó, F. Synthesis and Catalytic Properties of New Water-Soluble Ruthenium(II)-NHeterocyclic Carbene Complexes. Organometallics 2004, 23, 5640-5643.

(53) Lipke, M. C.; Liberman-Martin, A. L.; Tilley, T. D. Electrophilic Activation of Silicon-Hydrogen Bonds in Catalytic Hydrosilations. Angew. Chem. Int. Ed. 2017, 56, 2260-2294. 
(54) Yang, J.; White, P. S.; Schauer, C. K.; Brookhart, M. Structural and Spectroscopic Characterization of an Unprecedented Cationic Transition-Metal $\eta 1$-Silane Complex. Angew. Chem. Int. Ed. 2008, 47, 4141-4143.

(55) Luo, X. L.; Crabtree, R. H. Homogeneous Catalysis of Silane Alcoholysis via Nucleophilic Attack by the Alcohol on an $\operatorname{Ir}($.eta.2-HSiR3) Intermediate Catalyzed by [IrH2S2(PPh3)2]SbF6 (S = Solvent). J. Am. Chem. Soc. 1989, 111, 2527-2535.

(56) Hamdaoui, M.; Ney, M.; Sarda, V.; Karmazin, L.; Bailly, C.; Sieffert, N.; Dohm, S.; Hansen, A.; Grimme, S.; Djukic, J.-P. Evidence of a Donor-Acceptor $(\mathrm{Ir}-\mathrm{H}) \rightarrow \mathrm{SiR} 3$ Interaction in a Trapped Ir(III) Silane Catalytic Intermediate. Organometallics 2016, 35, 2207-2223.

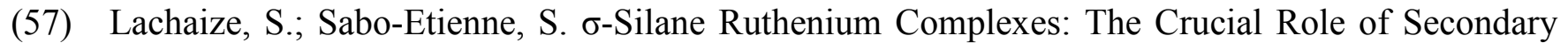
Interactions. Eur. J. Inorg. Chem. 2006, 2006, 2115-2127.

(58) Garcés, K.; Fernández-Alvarez, F. J.; Polo, V.; Lalrempuia, R.; Pérez-Torrente, J. J.; Oro, L. A. Iridium-Catalyzed Hydrogen Production from Hydrosilanes and Water. ChemCatChem 2014, 6, 1691-1697.

(59) Iglesias, M.; Sanz Miguel, P. J.; Polo, V.; Fernández-Alvarez, F. J.; Pérez-Torrente, J. J.; Oro, L. A. An Alternative Mechanistic Paradigm for the $\beta$ - Z Hydrosilylation of Terminal Alkynes: The Role of Acetone as a Silane Shuttle. Chem. Eur. J. 2013, 19, 17559-17566. 


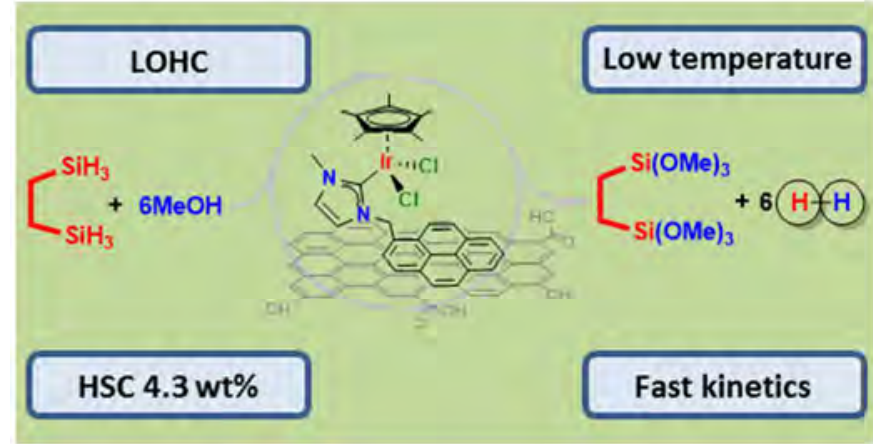

